\title{
Sedimentology and Geochemistry of the Makran Coastal Sediments Located in Southeastern Iran
}

\author{
Ahrari-roudi, Moyeddin, M.A.Zainudini \\ Assistant professor, Department of Basic Sciences, Faculty of Marine Sciences, \\ Chabahar Maritime University, Chabahar, Iran \\ M.Ahrari@cmu.ac.ir, mazainudini@yahoo.com
}

\begin{abstract}
Geochemical and sedimentary characteristics of the coast sediments between Lipar and Pozm Gulf in Southeastern of Iran have been investigated by taking 23 sediment samples. Samples of sediment were collected using of coring Euger in the tidal zones. On the basis of this research, 12 sedimentary types are identified that the dominant type are muddy sand, sand and sandy mud. Clastic components in sedimentary types, a collection of minerals, quartz, calcite, feldspar, iron oxides, clay minerals and are Ooid. Non-clastic components include fossil shell fragments. Geochemical study of coast sediments such as correlation coefficient, cluster diagram and factor analysis indicate four classification of elements enrichment base on source. (I) Elements such as $\mathrm{Cr}, \mathrm{Zn}, \mathrm{Mn}, \mathrm{Co}, \mathrm{Mg}, \mathrm{Ti}, \mathrm{Fe}, \mathrm{Sc}$ and $\mathrm{Ba}$, that the highest correlation and the origin of outside the basin (Geogenetic). (II) This group of chemical elements are biological in origin (Biogenetic) and include $\mathrm{Sr}, \mathrm{Ca}$ and P. (III) The third group of this elements are $\mathrm{Pb}$ and $\mathrm{Cu}$ that anthropogenic source and known as environmental pollutants. (IV) Finally, the fourth group includes elements Na and Li are related to evaporate sediments.
\end{abstract}

Keywords: Geochemistry, Sedimentary, Coast sediments, Estuary, Makran

\section{INTRODUCTION}

Marine sediments containing background of variable surface conditions, especially in the coastal strip of the background deposit is to document the various changes. The environment plays a very important role in the reproductive biology of the oceans (Bianchi, 2007). Fresh Water Rivers enter the sea when they are due to major differences in ionic strength, $\mathrm{Eh}$ and $\mathrm{pH}$, salinity and other areas where the marine environment, their interaction and this is a result of the reaction is deposition or dissolution. Coastal areas are also areas where important anthropogenic processes occur. (Bertollotto et al, 2005). So these are areas under severe stress. Therefore, the geochemistry of the open ocean is very uniform from the edge of the sea geochemical environment (Eby, 2005). The metallic elements naturally during the cycle of weathering, erosion, transport and so on by nature or is abnormal due to industrial activities into rivers and seas, is an important issue and geochemical studies of these elements can log volume and concentration in coastal and seabed sediments estimated (Berrow, 1991).On the other hand, grain sediment concentrations in marine sediments is very important (Merian et al, 2004; Ungaro et al, 2008).In general, most metals in fine-grained sediments (clay and silt) that has a diameter less than 63 microns are concentrated there. This is due to strong absorptive properties of clay minerals (Krumgalz et al, 1992).However, Ungaro et al, 2008) showed that the relationship between the concentration of heavy metals in sediments and silt and clay, sometimes complex and not easily. For example, in some marine sediment, silt, clay and concrete and are coarser particles that absorb or dissolve elements do not follow the law. Type of deposits and dynamics movement, affecting on the factors the concentration and fate of the elements are in them. In coastal areas with low hydrodynamic energy, the particles tend to sink and accumulate, while in areas with high hydrodynamic energy particles are washed and moved to the far side of the beach.

\section{GeOlOGY OF THE STUDY AREA}

The Makran Trench is the physiographic expression of a subduction zone which lies along the southwestern coast of Baluchistan (Pakistan) and Iran, where the oceanic crust of the Arabian Plate is subducting beneath the continental crust of the Eurasian Plate. In the Makran region, the Arabian 
Plate subducts beneath the Eurasian Plate at $\sim 4 \mathrm{~cm} / \mathrm{yr}$. This subduction is associated with an accretionary wedge of sediments which has developed since the Cenozoic (Kopp et al, 2000). To the west, the Makran Trench is connected by the Minab Fault systems to the Zagros fold and thrust belt (Regard et al, 2010). To the east, the Makran Trench is bounded by the transpressional strike-slip Ornach-Nal and Chaman Faults, which connect to the Himalayan orogeny.

The study area between latitudes 25 degrees to 25 degrees and 45 minutes north and longitude 55 degrees 45 minutes lengths up to 61 degrees and 30 minutes north of the Sea of Oman and the northeastern Sistan-Baluchistan province is located. From the perspective of geology of this area is located in this region, this region is structurally the two outer parts (coastal) and an internal split. The study area is located in the external part, the structure of the Makran coastal land area larger than the selected range (Fig. 1).

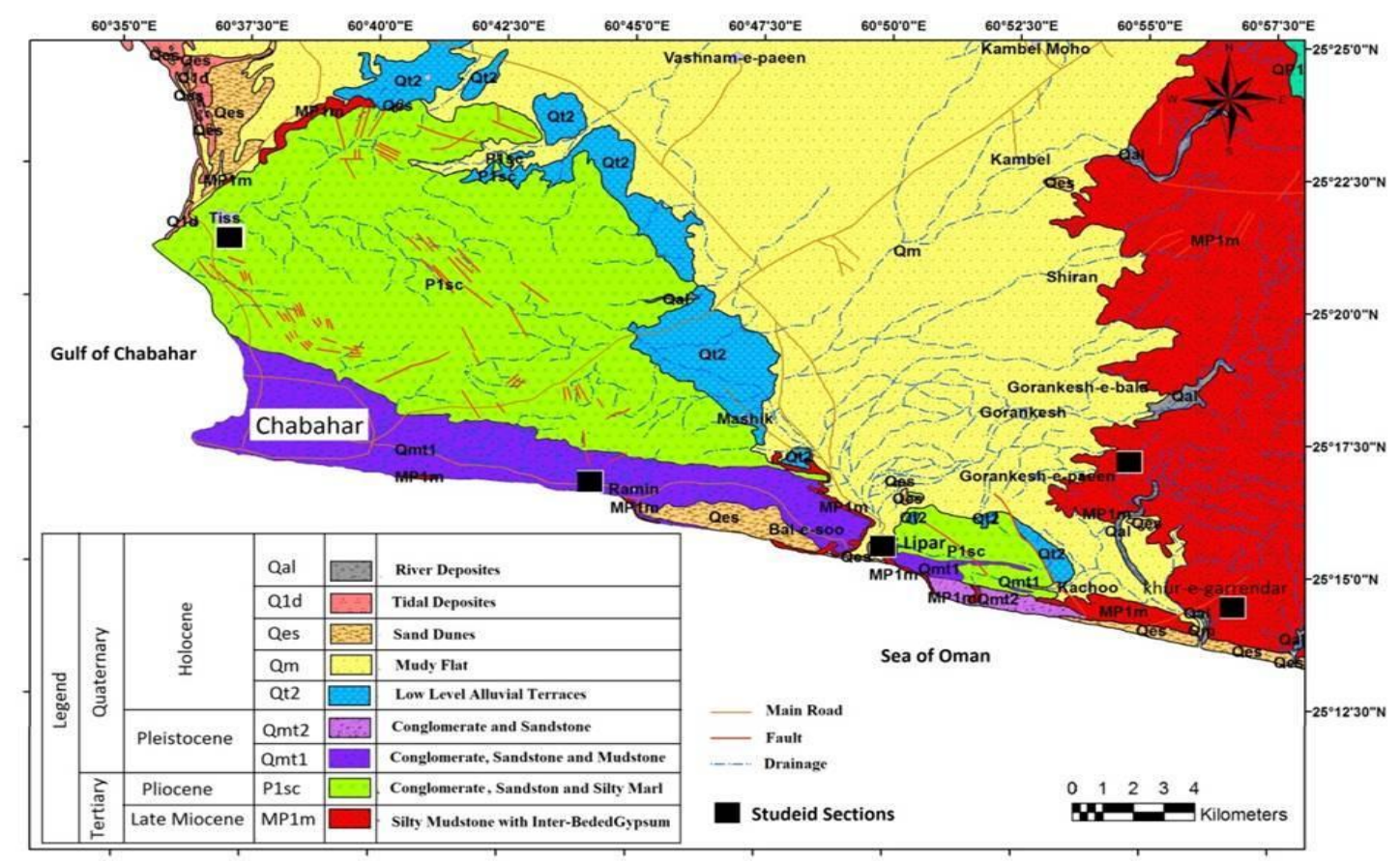

Fig 1. Geological map of Makran coast (summary based on maps of 1: 100000 Chabahar)

Basic features of this section of ophiolite flysch facies sedimentary deposits and non-exposed are older rocks of the Cretaceous (McCall, 1997). Ophiolite complexes of the region, more and more or less continuous strips are often outcrops along the main longitudinal fault (Jacob \& Quittmeyer, 1979).On the other hand, the study area, including areas where due to specific conditions of climate and geology of the sea level fluctuations during the various geological processes of weathering and erosion and tectonic activity caused by the subduction of Oman and up Makran bulge screen, unique structures and mainly clastic sedimentary rocks formed (Farhoudi \& Craig, 1977).Different rock units in the coastal zone and land overlooking the sea are marl of Miocene age, marl and sandstone units Miocene-Pliocene sediments of sand and silt deposits of alluvial fans and animal shells. Generally, sequence stratigraphy, the study area four Mio-Pliocene rocks, rocks Miocene, Pliocene and Quaternary rock units have been formed rock units that Neogene and Quaternary units are known as. Quaternary deposits in the Makran coastal sediments of the Pliocene stratigraphic column on the Pliocene conglomerate fall, but in the study area includes the coastal areas. Another important part of sediments in the study area are sedimentary deposits of creeks in the area. Among the most important coastal estuaries can be worthy of Pozm, Konarak, Parak, Ab-shirinkon, Tis, Tiab, Ramin and Lipar noted. Most structures worthy of sedimentary deposits, the traces of bioturbation and Boring by organisms.

\section{Materials ANd Methods}

Lipar wetland field studies and sampling at the interface between East and Gulf coastal strip south of the country do not cook in the West. The geographic location and characteristics of the collected samples were collected in Table 1. According to a study by the sediments carried coastal sediments of the Gulf of Oman, clastic sediments into the sea by rivers are seasonal and also within the basin 
sediments and sediments are wind, sampling of coastal and mouth area was estuaries. 23 sediment cores taken from the surface which were studied sedimentology and geochemistry. Selected samples of the sediment cores were stored in plastic bags and packaging. The cores were prepared of surface deposits all coastal estuaries in the study area. Sediment samples were screened (Using a Sieve shaker) and sedimentology studies and reviews textural and mineralogical samples, particles larger than 250 microns were examined, using a light microscope (Tucker, 2001). Series includes six sieve was used to from top to bottom in the size of $2 \mathrm{~mm}, 1 \mathrm{~mm}, 500$ microns, 250 microns, 125 microns and 63 microns. The samples are then dried in the oven, measured with digital scales (Tucker, 1988) and particles smaller than 63 microns by Laser Particle Sizer in Geological Survey of Iran were laser grading analysis. At this stage 200 grams of each sample were separated and placed in distilled water for 24 hours until the grains are separated attached. Then, to prevent the binding clay and crushed shells of oyster lack of ultrasound were stirred for 15 minutes. Then, in a series of sieves (model Analysette 30) has been wet for 30 minutes, the grain sizes were separated. Finally, the deposition of homogeneous and screenings (diameter less than 63 microns) were sent to the laboratory for chemical analysis. Chemical analysis of samples is done by ICP- OMS JY 70 PLUS model and ICP Optical Emission Spectrometer Varian 735-ES model.

Table 1. Assign locations of samples collected in the study area

\begin{tabular}{|c|c|c|c|}
\hline Placesamples & Longitudeandlatitude & Ablation depth $(\mathrm{cm})$ & Sample No. \\
\hline Lipar & $\mathrm{N} 25^{\circ} 1528^{\prime \prime} \& \mathrm{E} 60^{\circ} 4947^{\prime \prime}$ & 600 & L-1 \\
\hline Tiss & $\mathrm{N} 25^{\circ} 21^{3} \quad \& \mathrm{E} 60^{\circ} 38^{\prime \prime}$ & 160 & $\mathrm{~T}-2$ \\
\hline \multirow{6}{*}{ Shoor } & $\mathrm{N} 25^{\circ} 25^{\prime} 40^{\prime \prime} \& \mathrm{E} 60^{\circ} 36^{\prime} 16^{\prime \prime}$ & 634 & Sh-3 \\
\hline & $\mathrm{N} 25^{\circ} 25^{\prime} 36^{\prime \prime} \& \mathrm{E} 60^{\circ} 38^{\prime} 23^{\prime \prime}$ & 200 & Sh-4 \\
\hline & $\mathrm{N} 25^{\circ} 25^{\prime} 33^{\prime \prime} \& \mathrm{E} 60^{\circ} 38^{\prime} 19^{\prime \prime}$ & 900 & Sh-5 \\
\hline & $\mathrm{N} 25^{\circ} 25^{\prime} 34^{\prime \prime} \& \mathrm{E} 60^{\circ} 38^{\prime}$ & 435 & Sh-6 \\
\hline & $\mathrm{N} 25^{\circ} 25^{\prime} 35^{\prime \prime} \& \mathrm{E} 60^{\circ} 38^{\prime \prime \prime}$ & 515 & Sh-7 \\
\hline & $\mathrm{N} 25^{\circ} 24^{\prime \prime} \& \mathrm{E} 60^{\circ} 37^{\prime \prime}$ & 460 & Sh-8 \\
\hline \multirow{8}{*}{ Parak } & $\mathrm{N} 25^{\circ} 26^{\prime} 44^{\prime \prime} \& \mathrm{E} 60^{\circ} 34^{\prime} 11^{\prime \prime}$ & 300 & P-9 \\
\hline & $\mathrm{N} 25^{\circ} 2638^{\prime \prime} \& \mathrm{E} 60^{\circ} 34^{\prime} 14^{\prime \prime}$ & 650 & $\mathrm{P}-10$ \\
\hline & $\mathrm{N} 25^{\circ} 2616^{\prime \prime} \& \mathrm{E} 60^{\circ} 33_{48}^{\prime \prime}$ & 250 & P-11 \\
\hline & $\mathrm{N} 25^{\circ} 26^{\prime} 23^{\prime \prime} \& \mathrm{E} 60^{\circ} 33^{\prime \prime} 50^{\prime \prime}$ & 630 & P-12 \\
\hline & $\mathrm{N} 25^{\circ} 2626^{\prime \prime} \& \mathrm{E} 60^{\circ} 33^{4} 47$ & 415 & P-13 \\
\hline & $\mathrm{N} 25^{\circ} 26^{\prime} 21^{\prime \prime} \& \mathrm{E} 60^{\circ} 3351^{\prime \prime}$ & 500 & P-14 \\
\hline & $\mathrm{N} 25^{\circ} 26^{\prime \prime} 19^{\prime \prime} \& \mathrm{E} 60^{\circ} 33^{\prime \prime \prime}$ & 120 & P-15 \\
\hline & $\mathrm{N} 25^{\circ} 26^{2} 20^{\prime \prime} \& \mathrm{E} 60^{\circ} 33 \quad 46$ & 160 & $\mathrm{P}-16$ \\
\hline \multirow{4}{*}{ Ab-shirinkon } & $\mathrm{N} 25^{\circ} 26^{\prime} 37^{\prime \prime} \& \mathrm{E} 60^{\circ} 32^{\prime} 09^{\prime \prime}$ & 235 & A-17 \\
\hline & $\mathrm{N} 25^{\circ} 26^{\prime} 36^{\prime \prime} \& \mathrm{E} 60^{\circ} 31^{\prime \prime} 29^{\prime \prime}$ & 105 & A-18 \\
\hline & $\mathrm{N} 25^{\circ} 26^{\prime} 20^{\prime \prime} \& \mathrm{E} 60^{\circ} 29^{\prime} 21^{\prime \prime}$ & 580 & A-19 \\
\hline & $\mathrm{N} 25^{\circ} 26 \quad 19^{\prime \prime} \& \mathrm{E} 60^{\circ} 2920^{\prime \prime}$ & 505 & A-20 \\
\hline Konarak & $\mathrm{N} 25^{\circ} 24^{\prime} 15^{\prime \prime} \& \mathrm{E} 60^{\circ} 25^{\prime} 04^{\prime \prime}$ & 380 & $\mathrm{~K}-21$ \\
\hline \multirow[b]{2}{*}{ Pozm } & $\mathrm{N} 25^{\circ} 21^{\prime \prime} \& \mathrm{E} 60^{\circ} 20^{\prime}$ & 645 & $\mathrm{Z}-22$ \\
\hline & $\mathrm{N} 25^{\circ} 21^{\prime} 34^{\prime \prime} \& \mathrm{E} 60^{\circ} 19$ & 650 & Z-23 \\
\hline
\end{tabular}

\section{DiSCUSSION}

\subsection{Sedimentology (Grain Analysis)}

Granulation studies have been conducted on sediments indicate that components in a variety of sizes clastic sediments of sand, silt and clay formations that erosion upstream and carried by the wind and river have into basin. In samples of sediments, clay-sized particles are the most abundant components of the sediments (Fig. 2). Sized particles of silt, sand and gravel were put into place later. Environmental factors such as depth, temperature, salinity, and biological context of turbulence, distribution and development of carbonate organisms in the environment, are controlled by identifying the skeletal particles. In coastal estuaries sediments by increasing the amount of sediment sorting the amount of Skewness towards is closer to the symmetry. Analysis of sediment samples taken show that the sand on the beach with good sorting and Skewness of sand dunes negative and a positive Skewness is probably due to the small amount of parts in fossil sand beach. Clastic particles such as quartz, feldspar, carbonate and clastic biochemical particles are mainly parts bivalve shells. In addition to skeletal and non-skeletal components of organic matter in the sediment cores, observed gypsum and halite evaporate minerals, pieces of wood, laminated layers of mud and red. The 
sedimentological studies have been conducted and the size of sediments, according to the triangular diagram Folk (1974) in the sediments studied 12 types of sediments (including mud, sand, gravelly mud, gravelly sand, slightly gravelly muddy sand, slightly gravelly sandy mud, muddy sand, sandy mud, slightly gravelly sand, slightly gravelly mud, gravelly sandy mud and gravelly muddy sand) were identified as the predominant type is sandy mud sediments. The coastal sediments are mostly sandy type. The types of sedimentary facies of the two faces of the first (Facies mud, gravelly mud, slightly gravelly sandy mud, sandy mud, slightly gravelly mud and gravelly sandy mud) and second (Facies sand, gravelly sand, slightly gravelly muddy sand, muddy sand, slightly gravelly sand and gravelly muddy sand) categories are facies.

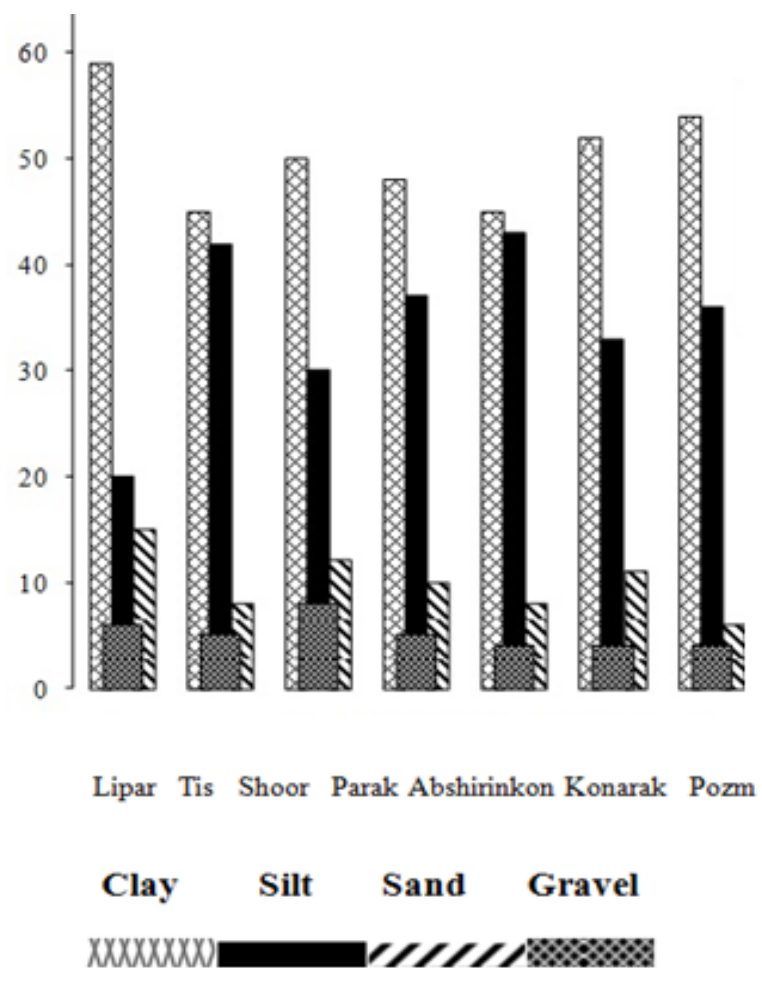

Fig 2. Diagram of grains Frequency gravel, sand, silt and clay sediment samples at various stations in the study area

Sedimentology studies indicate the sand-sized grains of sediment, sorting and roundness are good and no clay matrix, although deposition in the intertidal and sedimentary facies which consists of fine and coarse with bad sorting and clay matrix are contained in sedimentary environments of Supratidal been formed. Since the amount of Tissue maturity deposits to the amount of mechanical energy in the environment are interrelated and nothing to do with energy deposition in the final stages of transport from origin to depositional environment, so that the amount of energy in the environment much tidal sediments the Tissue maturation better and always there between Tissue and depositional environment of compliance. It appears in the coastal estuaries deposition of a dual regime has been ruling means that the rise in sea level and sediment deposition of carbonate and clastic sediment stops and took down the sea level and particle contamination clastic sedimentary basin, carbonate sedimentation stopped and sedimentation clastic is done. Coastal estuaries Chabahar Bay in North East, including salty estuaries and parks due to the closure of the mouth of the estuaries with tidal flows and assault are limited areas; the tidal facies zone extends to the sea and leaving deposits, expanded.

\subsection{Components of Sediments}

Since different species of organisms in marine, brackish and freshwater live, skeletal and non-skeletal parts were found in surface sediments of the study area. In the study area due to the proximity of the environmental, chemical and biochemical particles to each other and also clastic carbonates, carbonates and clastic particles from each other, there was complete separation of components can be classified particles of clastic sedimentary and biochemical deposits. The Clastic sedimentary is units in various sizes of sand, silt and clay. These deposits have been good sphericity, but mainly coarse crushed seashells, both are very bad sphericity. The clastic sedimentary particles of clay, quartz, feldspar, carbonate debris, in rocks of sandstone and limestone and minerals are opaque (Fig. 3). 

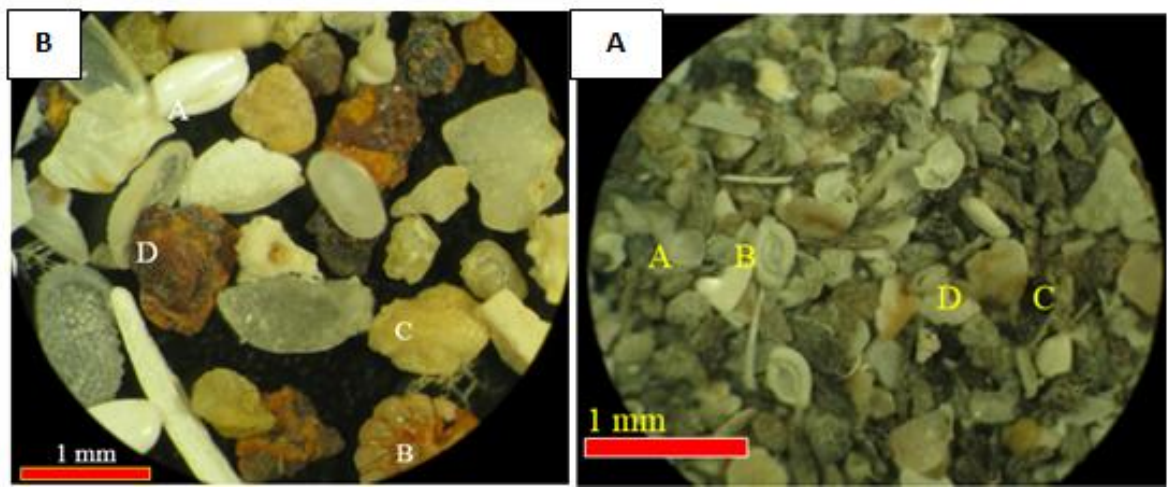

Fig 3. particles of sediments, indicating a lack of sorted sediments, Gastropod (A), Rotalia (B) Rock fragment (limestone) (C) and in rock fragment (sandstone) (D) (Figure A). Components of sediments, in shell mollusks $(A)$, Miliolides $(B)$, quartz $(C)$ and in rock fragment (limestone) (D) (Figure B)

Quartzite of various sizes as silt to coarse sand and gravel is sometimes observed in sediments. These particles are usually sun and perfectly round and spherical form, which is due to continuous erosion by currents, waves and tidal flows. Detrital carbonates are seen mainly as silt and sand, with roundness are pretty good that has been achieved as a result of transportation by river. The biochemical sedimentary components (skeletal) deposits within the study area and in parts of the shell bivalves, gastropods, small pieces of crabs, echinoderms spines, in coral, annelids and so on. These groups are especially bivalves and gastropods as well as smoking and healthy which indicates the amount of energy seen in the sediment basin conditions (Fig. 4).

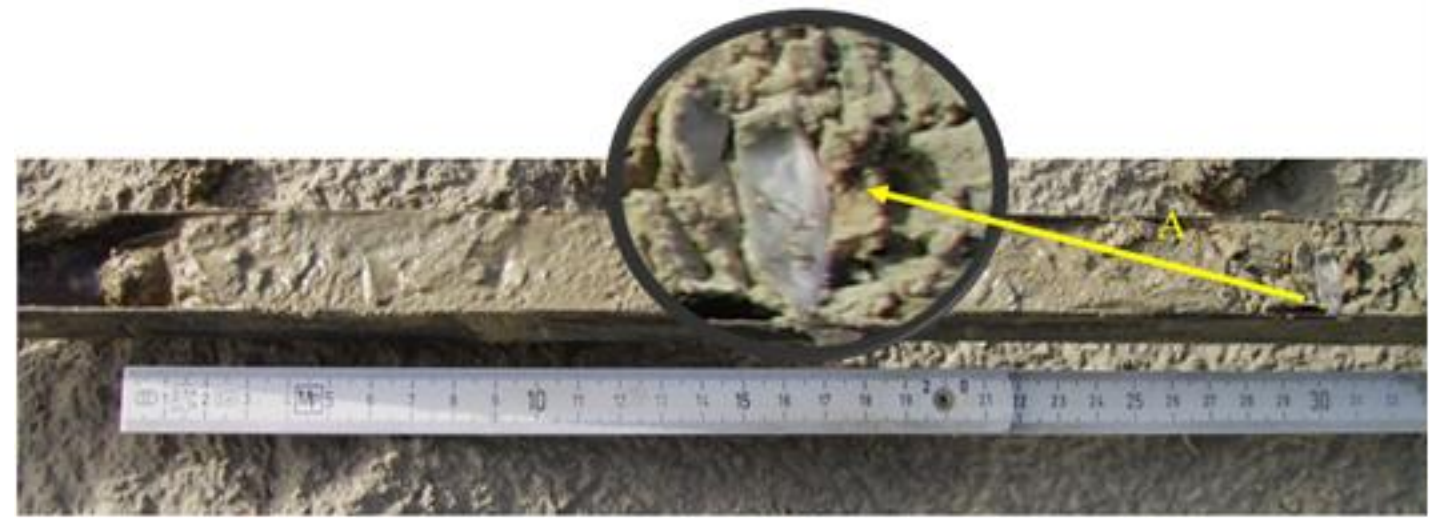

Fig 4. The portion of the core (6), a depth of $30 \mathrm{~cm}$, fossil mollusks (A), Shoor estuary station

\subsection{Sediment Geochemistry}

In Table 2, the concentration of major elements and heavy metals in sediment has been studied. As shown in the table shows the least amount of calcium element in sediments Lipar to the amount of $3.7 \%$ and $23.5 \%$ of its maximum in the sediment of the estuary area Parak. For Mg concentrations in sediments to the waterfront Tis $0.6 \%$ and $3.29 \%$ of its maximum in the sediment were worthy Pozm. The minimum amount of $\mathrm{Al}$ in sediments near the waterfront Tis, and the amount of $1.3 \%$ and a maximum of $5.6 \%$ was measured in the sediments of the estuary Parak. The minimum amount of $\mathrm{Na}$ element in sediments Port Tis the amount of $0.6 \%$ and a maximum of 2.9 percent was achieved in the estuary park. The minimum amount of $\mathrm{Fe}$ in the sediment of the estuary park to the amount of $1.07 \%$, and a maximum of 5.3 percent was observed in the sediments of the estuary Lipar. The minimum amount of $\mathrm{k}$ in the sediment of the estuary Tis to the amount of $0.17 \%$, and a maximum of 1.4 percent was observed in the sediments of the estuary Parak. The minimum amount of $\mathrm{Mn}$ in the sediment of the estuary park to the amount of 388ppm and a maximum of 632ppm was observed in the sediments of the estuary Tis. The minimum amount of Sr in the sediment of the estuary Pozm to the amount of 95ppm and a maximum of 2122ppm was observed in the sediments of the estuary Shoor. Among of the main elements $\mathrm{Al}$ and $\mathrm{Ca}$ concentrate in the sediment. The concentration of $\mathrm{Al}$ is closely related to grains size and generally fine-grained sediments contain more $\mathrm{Al}$ than the sediment. It seems that the focus of this element in the structure of clay minerals and clay minerals in sediments have an important role in increasing the concentration of Al. High concentration of $\mathrm{Ca}$ in the sediments because of the abundance of skeletal parts mollusks and other marine organisms, natural it seems. $\mathrm{Ca}$, 
$\mathrm{Mg}$ and strontium, the process is almost the same show. It seems that the origin of the basin and are biogenic and mainly $\mathrm{Ca}, \mathrm{Sr}$ and $\mathrm{Mg}$ in the calcareous shells and shell fragments of marine fossils, including mollusks and foraminifera, as well as calcium, strontium and magnesium dissolved in marl and argillaceous sediments easy release area, increasing the amount of these elements the cause. Another element of relatively large iron deposits in the region. Sedimento logical and mineralogical studies show that often a source of $\mathrm{Fe}$ in the sediment of the second type and include oxides and hydroxides of iron. Minerals hematite and magnetite, the heavy minerals are often found in all coastal sediments. The increase or decrease the amount of iron, potassium and aluminum in sediments associated with the mineralogy of the area and could be related to the presence or absence of alumino silicate minerals and clay minerals such as illite, vermiculite and montmorillonite. So in areas where clay minerals will increase, increased concentrations of aluminum and iron and potassium concentrations in sediments decreased vice versa. The concentration of sodium from 0.6 to 2.9 percentages changes and averages 1.7 percent. The minimum and maximum value has been achieved in the range of tees and the park. The amount of potassium can vary from 0.17 to 1.4 percent and an average of 1 percent. The concentration of this element was obtained in sediments adjacent waterfront park tees, and the highest concentration in estuary sediments. In the study area due to being in the hot and dry weather and low annual precipitation, evaporation of the water entering the river was higher and thus increases the weight of the element $\mathrm{Na}$. The $\mathrm{Fe}, \mathrm{Al}$ and $\mathrm{Mg}$ due to the arrival of clastic sediments increase in deposits of Noncarbonated (Clastics) and due to lack of clastic decrease in marine and carbonate sediments (Sageman, and Lyons, 2003). Therefore, increasing the values of these elements overcome clastics and carbonate sediments showed fall sea level. Due to low levels of sodium in the temperature, evaporation and humidity is lower sea levels, increased evaporation, reducing the amount of rainfall and humidity in the study area, greatly increases the value of this element. Therefore, sediment cores, $\%$ change represents the change in the relative level of sea water, so that changes in relative sea level curves with changes in weight amount of $\mathrm{Ca}, \mathrm{Sr}$ and $\mathrm{Mg}$ in direct proportion with the amount of $\mathrm{Fe}, \mathrm{Na}, \mathrm{K}, \mathrm{Al}$ and $\mathrm{Mg}$ is inversely proportional.

Table 2. Results of chemical analysis of samples collected from the study area (** Merian et al. 2004)

\begin{tabular}{|c|c|c|c|c|c|c|c|c|c|c|c|c|c|c|}
\hline $\begin{array}{l}\text { Sample No./ } \\
\text { Elements }\end{array}$ & $\begin{array}{c}\mathrm{Pb} \\
(\mathrm{ppm})\end{array}$ & $\begin{array}{c}\text { Co } \\
\text { (ppm) }\end{array}$ & $\begin{array}{l}\mathrm{Kd}(\mathrm{pp} \\
\mathrm{m})\end{array}$ & $\begin{array}{c}\mathrm{Cu} \\
(\mathrm{ppm})\end{array}$ & $\begin{array}{c}\mathrm{Zn} \\
(\mathrm{ppm})\end{array}$ & $\begin{array}{c}\mathrm{Ni} \\
(\mathrm{ppm})\end{array}$ & $\begin{array}{c}\mathrm{Cr} \\
(\mathrm{ppm})\end{array}$ & $\begin{array}{c}\mathrm{Mn} \\
(\mathrm{ppm})\end{array}$ & $\begin{array}{l}\mathrm{Na} \\
(\%)\end{array}$ & $\begin{array}{l}\mathrm{Mg} \\
(\%)\end{array}$ & $\begin{array}{l}\mathrm{Fe} \\
(\%)\end{array}$ & $\begin{array}{l}\mathrm{Ca} \\
(\%)\end{array}$ & $\begin{array}{c}\mathrm{K} \\
(\%)\end{array}$ & $\begin{array}{l}\mathrm{Al} \\
(\%)\end{array}$ \\
\hline$L^{*}-1$ & 17.4 & 23.1 & $<0.1$ & 27.8 & 96 & 121 & 125 & 541 & 1.4 & 2.4 & 5.3 & 3.7 & 2.3 & 7.4 \\
\hline $\mathrm{T}-2$ & 10.5 & 2.9 & $<0.1$ & 3.18 & 11.1 & 22.9 & 47.3 & 632 & 0.6 & 0.6 & 1.24 & 21.1 & 0.4 & 1.3 \\
\hline Sh-3 & 10.6 & 13.4 & 0.3 & 14.7 & 54.1 & 75.3 & 120 & 520 & 2.6 & 1.8 & 3.4 & 5.3 & 1.3 & 5.4 \\
\hline Sh-4 & 11.4 & 5.8 & 0.2 & 5.3 & 19 & 29 & 89 & 583 & 1.1 & 1.02 & 1.6 & 14.9 & 0.7 & 2.7 \\
\hline Sh-5 & 11.5 & 13.8 & 0.4 & 10.4 & 47 & 65.2 & 93.5 & 515 & 2.4 & 1.5 & 2.9 & 5.6 & 1.2 & 5 \\
\hline Sh-6 & 11.9 & 12 & 0.3 & 12.1 & 53.7 & 64 & 104 & 516 & 2.3 & 1.5 & 2.9 & 5.5 & 1.1 & 4.9 \\
\hline Sh-7 & 9.2 & 7.8 & 0.3 & 8 & 31 & 48.6 & 79 & 554 & 2.3 & 1.2 & 2.1 & 6.5 & 0.9 & 3.8 \\
\hline Sh-8 & 10 & 8.7 & 0.1 & 9.4 & 33.4 & 52.6 & 77.7 & 529 & 2.4 & 1.2 & 2.2 & 5.8 & 0.9 & 3.9 \\
\hline P-9 & 16 & 13.8 & 0.3 & 18 & 59.3 & 75.6 & 137 & 571 & 2.9 & 2.6 & 3.7 & 3.8 & 1.4 & 5.6 \\
\hline $\mathrm{P}-10$ & 14 & 12.5 & 0.1 & 15.2 & 50.9 & 69.9 & 111 & 580 & 2.08 & 1.8 & 3.4 & 4.8 & 1.2 & 5.3 \\
\hline P-11 & 15.4 & 12.2 & $<0.1$ & 15 & 49 & 65.4 & 125 & 578 & 1.6 & 1.7 & 3.3 & 7.1 & 1.2 & 5.2 \\
\hline P-12 & 11.9 & 13.6 & $<0.1$ & 15.6 & 50 & 60.5 & 1.6 & 546 & 1.8 & 1.6 & 3.06 & 5.3 & 1.1 & 5.1 \\
\hline P-13 & 13 & 15.9 & $<0.1$ & 17.7 & 54 & 74.1 & 132 & 517 & 1.5 & 1.6 & 3.6 & 4.9 & 1.3 & 5.7 \\
\hline P-14 & 7.1 & 1.6 & $<0.1$ & 3.9 & 12.7 & 15 & 67 & 388 & 0.7 & 0.7 & 1.07 & 23.5 & 0.3 & 1.3 \\
\hline P-15 & 10 & 12.2 & $<0.1$ & 14.08 & 43.6 & 58 & 140 & 510 & 1.5 & 1.3 & 2.9 & 7.9 & 1.1 & 4.6 \\
\hline P-16 & 6.22 & 1.76 & $<0.1$ & 4.39 & 15.8 & 17.8 & 52.6 & 472 & 0.8 & 0.7 & 1.1 & 21.1 & 0.4 & 1.5 \\
\hline A-17 & 10.1 & 4.4 & 0.15 & 4.73 & 16.2 & 48.8 & 64.1 & 608 & 1 & 0.96 & 1.5 & 15.7 & 0.65 & 2.5 \\
\hline A-18 & 10.8 & 8.93 & $<0.1$ & 5.41 & 23.3 & 64.8 & 77.2 & 571 & 1.14 & 1.17 & 1.88 & 14.7 & 0.77 & 3.15 \\
\hline A-19 & 10.2 & 6.13 & 0.23 & 6 & 22 & 64.7 & 88.1 & 579 & 1.17 & 1.08 & 1.82 & 15 & 0.78 & 2.93 \\
\hline A-20 & 9.8 & 2.8 & $<0.1$ & 4.3 & 13.1 & 41.4 & 33.8 & 559 & 1.09 & 0.98 & 1.33 & 17.2 & 0.57 & 2.11 \\
\hline K-21 & 8.8 & 4.4 & 1.7 & 7.7 & 31.4 & 25 & 95.6 & 524 & 2.2 & 1.03 & 1.6 & 10.4 & 0.62 & 2.5 \\
\hline Z-22 & 11.8 & 6.4 & 1.04 & 10.2 & 29.2 & 35.9 & 106 & 446 & 2.2 & 1.9 & 1.8 & 11.2 & 0.8 & 2.7 \\
\hline Z-23 & 7.8 & 13.1 & 1.6 & 13 & 39.7 & 61.9 & 94.2 & 444 & 2.7 & 3.2 & 2.6 & 6.3 & 1.1 & 4.07 \\
\hline Average & 11.2 & 9.5 & 0.5 & 11 & 37.2 & 55.3 & 96.9 & 534 & 1.8 & 1.5 & 2.5 & 10.3 & 1 & 3.9 \\
\hline $\begin{array}{l}\text { Averagecontinental } \\
\text { crust** }\end{array}$ & 15 & - & 0.10 & 25 & 65 & 56 & 126 & 716 & - & 2.2 & 4.3 & - & - & - \\
\hline $\begin{array}{l}\text { Averageoceanic } \\
\text { crust*** }\end{array}$ & $0 / 5$ & - & $0 / 13$ & 81 & 78 & 144 & 317 & 1200 & - & $4 / 5$ & 7 & - & - & - \\
\hline
\end{tabular}

*Samples with the prefix (L) have been collected from Lipar, (T) from Tis (Sh) from Shoor, (P) from park, (A) from the desalination plant, $(\mathrm{K})$ from Konarak and $(\mathrm{Z})$ from the Gulf Pozm.

In Table 1, In addition to the original concentration, the concentration of heavy metals $(\mathrm{Cd}, \mathrm{Co}, \mathrm{Pb}$, $\mathrm{Cr}, \mathrm{Cu}, \mathrm{Ni}$, and $\mathrm{Zn}$ ) is also provided in sediments of the study area. According to the data in the table can be said that most of the concentration of heavy metals in sediments naturally and the average concentration in the crust (oceanic and continental) or less than that. Thus increasing the 
concentration of heavy metals is in sediment study $\mathrm{Cd}<\mathrm{Cu}<\mathrm{Pb}<\mathrm{Zn}<\mathrm{Ni}<\mathrm{Cr}$. In Figure 5 the frequency graph metals chromium, nickel, zinc and lead was shown in the seven plants. The graph showed the heavy metal most frequently is in Lipar station (Fig. 5). Heavy metals in sediments, metals, chrome, nickel and lead, respectively, average concentrations of 96.6, 55.3 and 11.2, with the highest concentrations in the sediment. However, the average concentration of these metals is far less than the average concentration is continental in the sediment. The highest concentration of $\mathrm{Cr}$ (140 $\mathrm{ppm}$ ) in the sediment of the river estuary to show case the Parak. Nickel also shows a trend similar to Chrome, but peak concentrations at $121 \mathrm{ppm}$ concentrations measured in the sediment Lipar. A similar trend indicates a common origin for the two elements chromium and nickel. It seems that the weathering and dissolution of basic and special ophiolite rocks above the rock most of this region, and transfer them park by the river in case of rain, the main cause of the metals chromium and nickel is enriched sediment. Heavy metals copper, lead and zinc as well as with each other to exhibit similar trends. This indicates that the role of human activities in increasing the concentration of these metals in the Gulf of Chabahar more of the impact of natural factors. Lead and zinc because it has a specific gravity of many, mostly in coastal areas increases their concentration. That's why high concentrations in coastal sediments coarse. However, increasing the concentration of these metals due to the sediments adjacent to the fishing pier Tis showed that the main reason for their increase is anthropogenic origin. So these changes are the result of levels of pollutants above the entrance to the pier for fishing boats and vessels is more. The reason for this anomaly transition metal particles beach by waves are the dominant source of the metal particles pouring oil port boats and ships in the sea water.

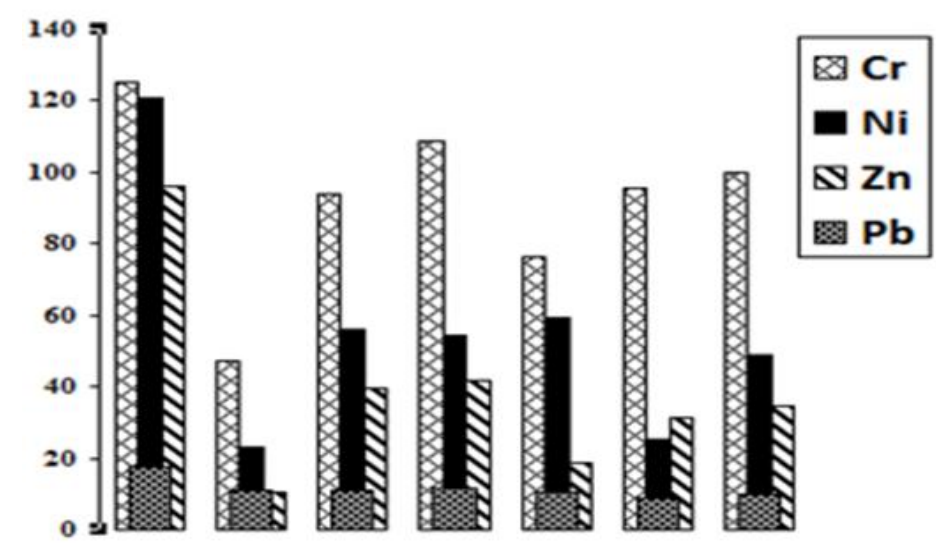

Lipar Tis Shoor Parak Abshirinkon Konarak Pozm

Fig 5. The Frequency distribution of heavy metals $(\mathrm{Pb}, \mathrm{Cr}, \mathrm{Ni}$, and $\mathrm{Zn})$ at different sampling stations

\subsection{Geochemical Data Processing}

In this research was to investigate the relationship between elements together and determine the origin of some statistical parameters, such as correlation and cluster diagram was studied. The correlation coefficient, Spearman method was used. The reason for choosing this method is that some elements are not normal distribution and Spearman correlation coefficient, independent of the distribution of elements. The correlation coefficient matrix elements are shown in Table 3 In this table, the significance of each of the correlation coefficients, the $95 \%$ confidence level, with a star and very significant, at $99 \%$, with two stars has been determined. Usually correlation coefficients of less than 0.2 indicate a weak correlation between the two variables. Correlation coefficients between $0.2-0.4$ are elements that indicate a weak correlation between the variables. In other words, the correlation coefficient is higher and closer to number 1 it is possible to estimate the correlation between the two most successful elements of the group (category) exists. Negative values mean that increasing one element, the other element is reduced and a negative correlation between the two elements. According to Table 3, four categories can be identified, together with good correlation. The first category consists of iron and aluminum, the latter includes elements strontium, calcium and phosphorus, lead and copper and the fourth, and the third category includes lithium, nickel and copper.

On the other hand, to determine the relationship between the elements together, the clustering method was used. Cluster analysis is a multivariate statistical method based on elements like the variability 
between them in the classified categories or groups. The cluster diagram drawn to elements of the study, the data can be viewed in three main groups (Fig. 6). The first group of scandium, iron, titanium, magnesium, potassium, aluminum, vanadium, sodium, cobalt, manganese, barium, lead, chromium and zinc, have close ties with each other and fall in a branch. In the second group elements, strontium, calcium and phosphorus showed the strongest relationship. In the third group elements, lithium, nickel and copper are placed in a directory (Fig. 7).

Table 3. Correlation coefficients between different elements in sediments of the study area

\begin{tabular}{|c|c|c|c|c|c|c|c|c|c|c|c|c|c|c|c|c|c|c|c|c|}
\hline & Co & $\mathbf{P}$ & $\mathbf{P b}$ & $\mathbf{L i}$ & $\mathrm{Ni}$ & Mn & Ba & $\mathrm{Cr}$ & $\mathrm{Cu}$ & Sc & $\mathbf{S r}$ & $\mathrm{Ti}$ & $\mathrm{V}$ & $\mathbf{Z n}$ & $\mathrm{Fe}$ & $\mathbf{K}$ & $\mathrm{Ca}$ & Al & $\mathbf{M g}$ & $\mathrm{Na}$ \\
\hline $\mathrm{Cu}$ & 1 & & & & & & & & & & & & & & & & & & & \\
\hline $\mathbf{P}$ & -.108 & 1 & & & & & & & & & & & & & & & & & & \\
\hline $\mathbf{P b}$ & .151 & -100 & 1 & & & & & & & & & & & & & & & & & \\
\hline $\mathbf{L i}$ & .013 & $.459^{* * *}$ & -.048 & 1 & & & & & & & & & & & & & & & & \\
\hline $\mathrm{Ni}$ & .047 & $.45^{* * *}$ & .005 & $.971^{* *}$ & 1 & & & & & & & & & & & & & & & \\
\hline Mn & -.184 & .106 & -.305 & .005 & -.060 & 1 & & & & & & & & & & & & & & \\
\hline $\mathbf{B a}$ & .192 & -.142 & -.212 & $.345^{*}$ & .299 & $.635^{* *}$ & 1 & & & & & & & & & & & & & \\
\hline $\mathrm{Cr}$ & $.436^{* *}$ & \begin{tabular}{|c|}
.099 \\
\end{tabular} & .193 & .188 & .263 & .002 & .256 & 1 & & & & & & & & & & & & \\
\hline $\mathbf{C u}$ & .066 & $-.371^{*}$ & .090 & $.466^{* *}$ & $.501^{* *}$ & .102 & $.475^{* *}$ & $.315^{*}$ & 1 & & & & & & & & & & & \\
\hline $\mathbf{S c}$ & $.424^{* *}$ & $\stackrel{-}{458}^{* *}$ & .027 & $.473^{* *}$ & $.504^{* *}$ & -.031 & $.555^{* *}$ & .289 & $.572^{* *}$ & 1 & & & & & & & & & & \\
\hline $\mathbf{S r}$ & -.182 & $.647^{* *}$ & .229 & $.603^{* *}$ & $-.505^{* *}$ & -.238 & $-.636 * \mid$ & -.108 & $-.324^{*}$ & $.614^{* *}$ & 1 & & & & & & & & & \\
\hline $\mathbf{T i}$ & $.586 *$ & -.297 & .165 & .203 & .275 & -.247 & $.365^{*}$ & $.517^{* *}$ & $.408^{* * *}$ & $.803^{* *}$ & $-.372^{*}$ & 1 & & & & & & & & \\
\hline $\mathbf{V}$ & $.562^{* *}$ & $-.322^{*}$ & .212 & .264 & $.327^{*}$ & -.249 & $.315^{*}$ & $.429^{* *}$ & $.422^{* *}$ & $.867^{* *}$ & $-.356^{*}$ & $.928^{* *}$ & 1 & & & & & & & \\
\hline $\mathbf{Z n}$ & $.389^{*}$ & -.154 & .076 & $.340^{*}$ & $.340^{*}$ & .093 & $.387^{*}$ & .162 & $.507^{* *}$ & $.441^{* *}$ & $-.359^{*}$ & .271 & $.352^{*}$ & 1 & & & & & & \\
\hline $\mathbf{F e}$ & $.487^{* *}$ &.${ }^{-} 4^{* *}$ & .115 & $.357^{*}$ & $.409^{* * *}$ & -.195 & $.432^{* * *}$ & $.357^{*}$ & $.593^{* *}$ & $.929^{* *}$ & $-.498^{* * *}$ & $.872^{* *}$ & $.928^{* *}$ & $.488^{* *}$ & 1 & & & & & \\
\hline $\mathbf{K}$ & $.319^{*}$ & $.557^{* * *}$ & \begin{tabular}{|l|}
.068 \\
\end{tabular} & $.717^{* *}$ & $.717^{* * *}$ & .006 & $.589^{* * *}$ & .276 & $.575^{* *}$ & $.916^{* *}$ & $-.759^{* * *}$ & $.667^{* *}$ & $.716^{* *}$ & $.459^{* *}$ & $.804^{* * *}$ & 1 & & & & \\
\hline $\mathrm{Ca}$ & -.297 & $.593^{* *}$ & .113 & $.515^{* *}$ & $-.449^{* * *}$ & -.097 & $-.634^{* *}$ & -.093 & $-.347^{*}$ & $.705^{* *}$ & $.925^{* *}$ & $-.495^{* *}$ & $.500^{* *}$ & $-.395^{*}$ & $-.632^{* * *}$ & $-.779^{* * *}$ & 1 & & & \\
\hline Al & $.320^{*}$ & $.654^{* *}$ & .014 & $.672^{* *}$ & $.652^{* * *}$ & - -127 & $.497^{* *}$ & .213 & $.500^{* *}$ & $.879^{* *}$ & $-.824^{* *}$ & $.660^{* *}$ & $.708^{* *}$ & $.425^{* *}$ & $.811^{* *}$ & $.945^{* *}$ & $-.884^{* * *}$ & 1 & & \\
\hline $\mathbf{M g}$ & $.472^{* *}$ & $-.358^{*}$ & $.382^{*}$ & .288 & $.361^{*}$ & $.544^{* *}$ & -.095 & .169 & $.322^{*}$ & $.666 *$ & -.132 & $.606^{* *}$ & $.756^{* *}$ & $.318^{*}$ & $.727^{* *}$ & $.525^{* *}$ & -.310 & $.584^{* *}$ & 1 & \\
\hline $\mathrm{Na}$ & $.376^{*}$ & $.475^{* *}$ & .008 & $.472^{* *}$ & $.424^{* * *}$ & .095 & $.494^{* *}$ & .050 & .273 & $.565^{* *}$ & $-.734 *$ & .278 & $.371^{*}$ & $.502^{* *}$ & $.501^{* *}$ & $.650^{* * *}$ & $-.795^{* *}$ & $.700^{* *}$ & $.395^{*}$ & 1 \\
\hline
\end{tabular}

**. Correlation is significant at the 0.01 level (2-tailed).

*. Correlation is significant at the 0.05 level (2-tailed)

Final processing and correlation in order to determine the relationship of elements was done based on the matrix composition, the method of rotating and factor analysis to determine the origin of sediments. The analysis conducted on the data, indicate that the elements are in 4 major groups that are closely connected. On the other hand the elements in sediment, with 4 origins respectively. The first group includes elements scandium, iron, titanium, magnesium, potassium, aluminum, vanadium, sodium, cobalt, manganese, barium, lead, and zinc cream with the highest correlation with terrestrial origin (Geogenic). There are seasonal rivers in the upstream catchment area, as well as the northern winds, have resulted in older rocks are transported and deposited them into the basin. Due to the frequency and ultra basic or basic rocks in tectonic area of Makran enriched sediments in the area of the elements to be expected. Due to the abundance of very alkaline and alkaline rocks in this region enriched sediments in the area of the elements to be expected. The second group includes elements strontium, calcium and phosphorus in the sediments of biological origin (Biogenic), and geochemical data, the correlation and cluster analysis are also confirmed. As mentioned in the review section changes the basic elements, elements such as calcium and strontium replacement oyster shells and other skeletal remains of marine animals, a conventional process. In the third group, the elements cadmium, lead and copper and zinc are associated with anthropogenic origin and impact of human and environmental pollution caused by marine vessels that enter the basin Oman Sea. Show that these elements dissolved in water tends to be associated with carbonates and carbonates are absorbed and then are deposited in sedimentary basin. Wastewater from repair, painting, refueling and oil change fishing boats, the most important factors is considered in increasing concentrations in sediments 
(Especially Sample near fishing ports). Finally, the fourth group elements including lithium and sodium which are associated with evaporate deposits in the region. Most enriched those elements were measured in the salty estuary sediment samples. In this area, numerous ponds by people Chabahar is made for extracting salt from sea water. Therefore, increasing the concentration of lithium and sodium salts can be caused by pollution in the sediment.

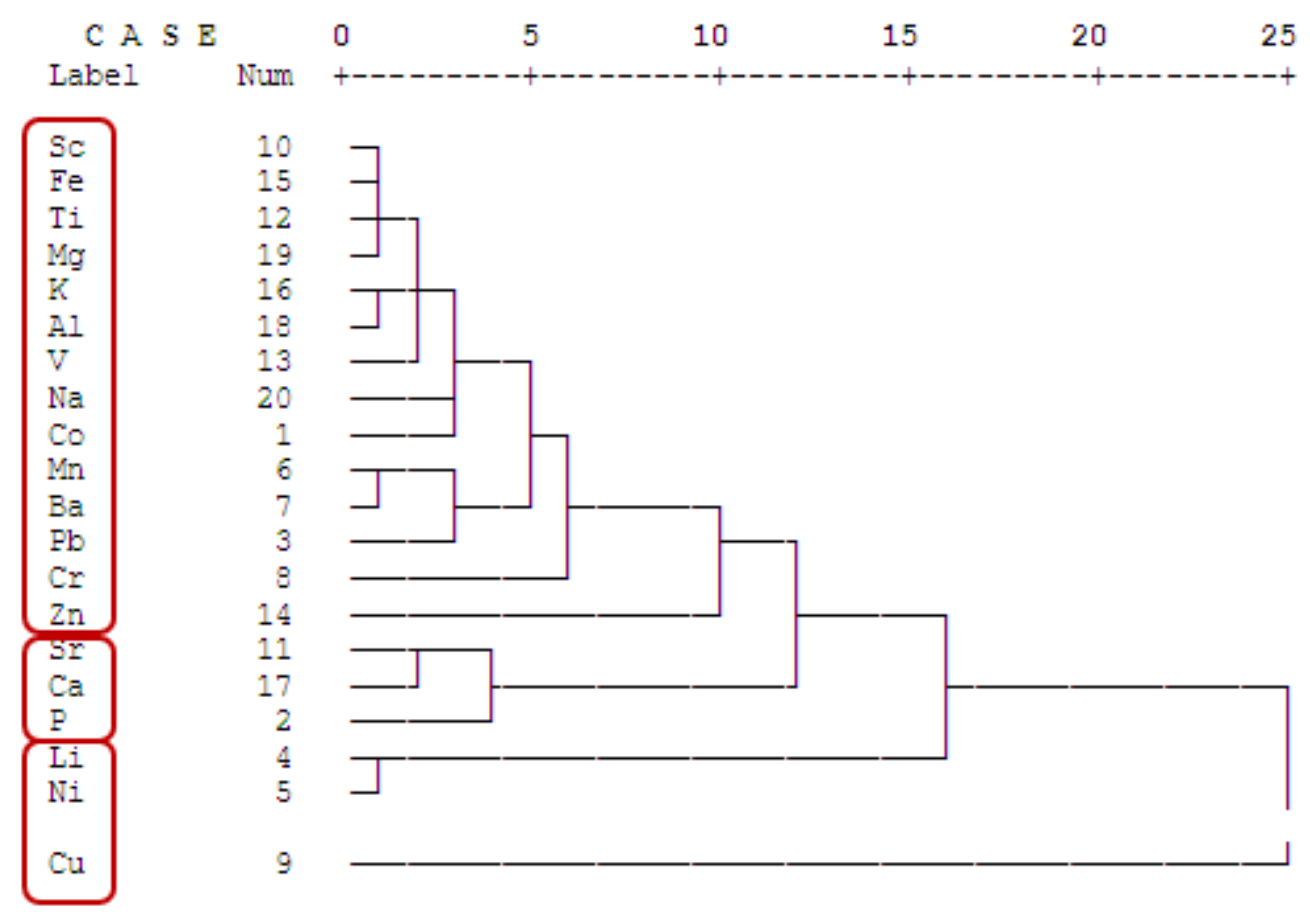

Fig 7. Cluster analysis frequency elements in sediments of estuaries north Coast of Oman Sea

\section{INTERPRETATION RESULTS AND CONCLUSION}

In this research geochemical and sediment logical characteristics of the sediments of the coastal strip between wetland Lipar South East of the country between the East and the Gulf of Pozm in the West, with sampling of surface sediments in coastal areas was conducted in seven different stations. The sediment logical studies, 12 were identified types of sediments that most types of sediments, sandy mud was diagnosed. Depositional environment has been restored to areas of intertidal and supratidal. Deposits of supratidal environment granulated and light brown adhesive, without water and with gypsum and quartz minerals that constructions such as cracks caused by the birds and flowers are abundant in them. Energetic environment intertidal sediments, mostly muddy sand with crushed shells are brown to light gray. A variety of algae, organic matter, making the bird's eye and biological disturbances are observed the sediments deposited in the environment. In total deposits of sedimentary estuaries (Creek Park and shoor estuary) are terminated from below to sediments of the tidal environment and from above to the open sea sediments which are usually fine-grained mud. So, in estuaries studied various deposits in terms of aggregation and Tissue deposition. Comparing the 23 core columns facies sediments (Fig. 8) to the conclusion that in the study area from the East to the West with the relative sea level fluctuations, sedimentary cycles of variable occurs, So that in the coastal estuary Tis, three advance and recession seawater desalination worthy Park and four advance and recession and the Gulf cook sea water taken three steps forward and recession. As the shoor, three advances and recession of the sea, the park and abshirinkon four advances and recession and the Gulf of Pozm sea water taken three steps forward and recession. Vertical and lateral changes in sedimentary facies along with physical evidence show those Holocene sediments deposited in the supratidal and intertidal in the study area. As the first group facies sedimentary environment (facies mud) related to the supratidal environment and sedimentary facies in the second (sandy facies) related to the intertidal environment. Geochemical studies of coastal sediments were evaluated in the context of the main elements and heavy metals. The study showed that heavy metal contamination of sediments is low and the concentration of most heavy metals in sediments in the normal way and the average concentration in the crust (oceanic and continental) or less of it, and only the rich disruption of these metals chromium and nickel concentrations observed that it is also natural origin. 


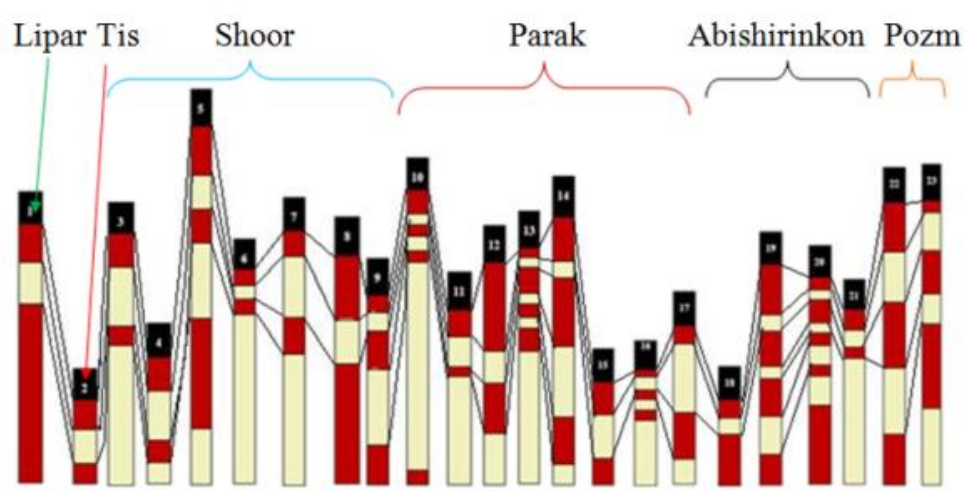

Fig 8. compliance facies sedimentary cores in the study area, the red color represent the top of the tidal and intertidal environment yellow indicator (scale 1: 150)

Curves of the changes of the relative sea level curve largely matches, So that the relative sea level curve, calcium and strontium values associated with fossil shells are in direct proportion and with the amount of iron and aluminum which are harmful sediments index is inversely proportional. The rising sea level, the values of strontium, calcium and phosphorus are increased in connection with shells and marine fossils, including mollusks and foraminifera and are biogenetic origin (Intra Basin). Scandium, iron, titanium, magnesium, potassium, aluminum, vanadium, sodium, cobalt, manganese, barium, lead, and zinc cream with the highest correlation are geogenic origin (Extra basin). Calculated correlation coefficients, and cluster diagram elements also represent the four origins, for the enrichment of the sediments studied: The first group consists of chromium, zinc, manganese, cobalt, magnesium, titanium, iron, scandium and barium. The elements of this group have the highest correlation with each other and seem to have originated from outside the basin (Extra basin). The second group consists of phosphorus; calcium and strontium are biochemical origin. The third group elements copper and lead mainly anthropogenic origin and are considered as polluting. Finally, the fourth group includes the elements lithium and sodium, which is closely associated with evaporite sediments region.

\section{REFERENCES}

[1] Berrow, S. D., 1991. Heavi metals in sediments and shellfish from Cork harbor, Ireland. Marine Pollution Bulletin, 22: 467-469.

[2] Bertollotto, R.M., et al. 2005. Heavy metals in coastal sediments of the Ligurian Sea off vado ligure. J. de phys., V. 107 (1), 159-162.

[3] Bianchi L. P. (2007). Forensic DNA and bioinformatics. Briefing in Bioinformatics8 (2): 117 128.

[4] Kopp, C.; Fruehn, E.; Flueh, E.; Reichert, C.; Kukowski, N; Bialas, J.; Klaeschen, D. (2000). "Structure of the Makran subduction zone from wide-angle and reflection seismic data". Tectonophysics 329: 171-191.

[5] Eby, G. N., 2005. Principles of environmental geochemistry, Thomson, Ellis, S., Mellor, A., New York.

[6] Farhoudi, G.; Craig, D. E., 1977. Makran of Iran and Pakistan as an active arc system. Geology, 5(11): 664-668.

[7] Folk, R.L., 1974. Petrology of sedimentary Rock: Hemphill publishing Co., Austin, Texas 182P.

[8] Jacob, K. H.; Quittmeyer, R. C., 1979. The makran region of Pakistan and Iran trench-arc system with active plate subduction. Geodynamics of Pakistan, 3: 305-318.

[9] Krumgalz, B.S., Fainshtein, G., Cohen, A., 1992. Grain size effect on anthropogenic trace metal and organic matter distribution in marine Sediments. Sci. Total Environ. 116, 15 \pm 30 .

[10] McCall, G. J. H., 1997. The geotectonic history of the Makran and adjacent areas of southern Iran. Earth Sciences, 15: 517-531.

[11] Merian, E., Anke, M., Ihnat, M., and Stoeppler, M., 2004. Elements and their compounds in the environment, John Willey, $1170 \mathrm{p}$.

[12] Regard, V.; Hatzfeld, D.; Molinaro, M.; Aubourg, C.; Bayer, R.; Bellier, O.; Yamini-Fard, F.; Peyret, M.; Abbassi, M. (2010). "The transition between Makran subduction and the Zagros 
collision: recent advances in its structure and active deformation". Geological Society, London, Special Publications 330 (1): 43-64

[13] Sageman, B.B. and Lyons, T.W., 2003, Geochemistry of Fine-grained Sediments and Sedimentary Rocks, Treatise on Geochemistry, V. 7, P. 115-158.

[14] Tucker, M.E., 2001, Sedimentary Petrology: an Introduction to the Origin of Sedimentary Rocks, Third edition, Blackwell Science, Oxford, 260 P.

[15] Ungaro, F., Ragazzi, F., Cappellin, R., and Giandon, P. 2008. Arsenic concentration in the soils of the Brenta Plain (Northern Italy): Mapping the probability of exceeding contamination thresholds. J. Geochem. Exp. 96: 117-131.

[16] Vaught, KC (1989), A Classification of the Living Mollusca, American Malacologists, 195 P. 